\title{
Do the melanophore dispersing hormones pass the cerebrospinal fluid-blood barrier of the killifish, Fundulus heteroclitus?
}

\author{
W. REA KNIGHT, JANET N. KNIGHT, and GRACE E. PICKFORD \\ Departments of Psychology and Biology, Hiram College, Hiram, Ohio 44234
}

\begin{abstract}
Experiments were made on male killifish, Fundulus heteroclitus, weighing ca. $10 \mathrm{~g}$, to determine whether the melanophore dispersing hormones, $\alpha$ - or $\beta$-MSH, could enter the general circulation after injection into the third brain ventricle. Each fish had an implanted cannula provided with a removable cap for intracranial injection. The presence of a dispersing hormone in the blood was detected by means of the darkening of a "faded denervated caudal band," described by Parker (1948). After injection, unanesthetized fish were observed for 60 min against a white background. Intraperitoneal injections of $.67 \mu \mathrm{g}$, or less, of either preparation, in $100 \mu \mathrm{l}$ of $.6 \% \mathrm{NaCl}$, elicited the expected darkening with a latency of $10.7 \pm .9$ (SEM) min; intracranial injections of the same dose in $.3 \mu \mathrm{l}$ had no effect (seven fish) or resulted in a scarcely detectable darkening with a long-delayed latency (three fish). The melanophore hormones, $\alpha$-and $\beta$-MSH pass the CSF-blood barrier with difficulty, if at all.
\end{abstract}

Injections of neurohypophysial peptides, such as arginine vasopressin or arginine vasotocin, into the body cavity of the killifish, Fundulus heteroclitus, elicit a characteristic spawning reflex response that may be abolished by lesions of the nucleus preopticus (Macey, Pickford, \& Peter, 1974). Since the effective dose is pharmacological and there is a long latency, it was thought that direct application of the peptide to the appropriate hypothalamic center might elicit a prompt response at a physiologically acceptable level. In order to test this hypothesis, we have been injecting neurohypophysial peptides and other possible effector agents into the third ventricle or adjacent brain tissue of brain-cannulated fish. Unpublished results, to date, have been essentially negative: a dose that was effective when injected into the body cavity was ineffective when injected into the third ventricle, unless damage to adjacent blood vessels could be demonstrated. This finding raised the question of the cerebrospinal fluid-brainblood barrier of the killifish.

Comparatively little is known regarding the bloodbrain barrier of teleost fishes (Bernstein \& Streicher, 1965; Lundquist, 1942; Obermüller-Wilén, 1972; Rahmann, 1970), although extensive research has been directed to this problem in elasmobranchs

This research was supported by a grant from the National Science Foundation, BMS75-18700. We thank Dr. Aaron B. Lerner and Dr. Saul Lande, Laboratory of Clinical Investigation, School of Medicine, Yale University, for the samples of alpha and beta MSH. Requests for reprints should be sent to Dr. Grace E. Pickford, Department of Biology, Hiram College, Hiram, Ohio 44234.
(Cserr, Fenstermacher, \& Rall, 1972; Fenstermacher \& Patlack, 1977; Fenstermacher, Patlack, \& Blasberg, $1974)$ and some studies have been made on cyclostomes (Murray, 1975; Murray, Jones, Cserr, \& Ball, 1975). In the rat, Greenberg, Whalley, Jourdikian, Mendelson, Walter, Nikolics, Coy, Schally, and Kastin (1976) have shown that labeled peptides injected into the carotid artery penetrate the bloodbrain barrier. These peptides include arginine vasopressin, in which we are particularly interested, and $\alpha$-MSH, which is known to have behavioral effects in mammals (Kastin, Sandman, Stratton, Schally, \& Miller, 1975). Transport studies of neurohypophysial peptides require the use of radioactive-labeled tracers, but a simple experiment can be made on killifish by use of the melanophore dispersing properties of the melanotropins, $\alpha$ - or $\beta$-MSH. Normally innervated melanophores of this species are unresponsive to melanotropins, but the investigations of G. H. Parker and his associates, reviewed by Parker (1948) and Waring (1963), revealed that if innervation is interrupted by severance of one or two fin rays there is an initial darkening, followed by gradual fading of the "denervated caudal band." When such fish are viewed against a white background, the caudal band can be seen to darken in response to intraperitoneal injections of melanotropin. This permits detection of the presence of dispersing hormones in the blood and, when viewed with care, can be evaluated in a semiquantitative manner. We have employed this procedure to determine whether $\alpha$ - or $\beta$-MSH, injected into the third brain ventricle, can escape into the peripheral circulation of the killifish. 


\section{METHOD}

Male Fundulus heteroclitus, weighing about $10 \mathrm{~g}$, were purchased from a dealer (W. J. Cameron, Howard Beach, N. Y.). They were maintained in artifical salt water (Instant Ocean, Aquarium Systems Inc., Eastlake, Ohio) with a salinity corresponding to that of Long Island Sound (3\%). The temperature was regulated at $19^{\circ} \pm 1^{\circ} \mathrm{C}$, and illumination, with standard aquarium reflectors, was restricted to a short winter daylength $(8 \mathrm{~h}$ light, $16 \mathrm{~h}$ dark). The fish were fed daily with a modification of Aronson's formula (Aronson, 1949) supplemented with a trace of iodine (Pickford, 1953).

In preparation for the experiment, two fish were placed in each of the required number of $20 \mathrm{gal}$ aquaria containing 60 liters of water. The fish were separated by a perforated partition to reduce the likelihood of damage to the cannulae through social interactions or increased activity. Aeration was provided for each compartment and white tiles were placed on the bottom to ensure white-background adaptation. Ten or 11 days later, 16 fish were operated on for implantation of a brain cannula and, at the same time, a caudal band was initiated by transecting one or two fin rays. The caudal bands were not completely faded, 7 or 8 days later, when some fish were injected with a low dose of $\beta$-MSH $(.14 \mu \mathrm{g} / \mathrm{fish})$. A second cut was made on the following day. After 3-8 days, when the second caudal band was partially and the first completely faded, all fish were given injections of either $\alpha$ - or $\beta$-MSH, according to the schedule given in Table 1 , in which the first injection day is designated as Day 1. Subsequent injections were given on alternate days to allow for fading of a temporarily darkened caudal band. No anesthetic was used, since this results in melanophore dispersion. Intraperitoneal injections were made into the body cavity by inserting a 26 -ga needle, attached to a $1 / 4-\mathrm{ml}$ syringe containing the required dose, through the soft skin of the cloacal region, care being taken to avoid giving an enema. The procedure for intracranial injections is described below. Half the fish received intraperitoneal injections before, and half subsequent to, an intracranial injection. The latency column in Table 1 indicates the time in minutes when the first faint darkening could be observed. The maximal response during $60 \mathrm{~min}$ of continuous observation against a white background is rated as follows: $0=$ no darkening, $1=a$ faint but just detectable darkening, 2 = definite darkening, and $3=$ intense darkening.

One or 2 days after the last injection, all fish were given intracranial injections of a suspension of India ink. The heads were fixed in $4 \%$ formaldehyde, and, subsequently, the cannula was withdrawn and the brain removed from the skull, embedded in paraffin, and sectioned at 10 microns. The sections were stained with cresyl violet.

\section{Implantation of Brain Cannula}

Cannulation procedures were developed by the first author in collaboration with Dr. R. E. Peter at the University of Alberta in August 1974, and those applicable to 60-g goldfish have been described by Peter and Billard (1976). Some modifications were necessary for the killifish, weighing only about $10 \mathrm{~g}$, that were employed in our experiments.

The cannula was made from 30-ga stainless steel tubing, $9 \mathrm{~mm}$ in length and containing $.1 \mu \mathrm{l}$ in the lumen. Three millimeters of No. $20 \mathrm{PE}$ tubing was slipped onto the midsection of the cannula. A short length of Ethicon surgical tantalum wire (.007 diam) was twisted around the PE tubing, and a small loop was formed in the ends of the wire, which extended approximately $2 \mathrm{~mm}$ out from the cannula. The wire and the PE tubing were glued in place with a drop of Duradix (Wm. Dixon Co., N. J.) and provided an anchoring surface when the appliance was cemented to the skull.
Fish were anesthetized in. $\mathbf{4 \%}$ tricaine methanesulfonate (Finquel, Ayerst Laboratories, Inc.) and wrapped in moistened paper tissue. Approximately six scales were removed from the dorsal surface of the skull and a section of frontoparietal bone, about $3 \mathrm{~mm}$ wide and $2 \mathrm{~mm}$ in the anterior-posterior plane, was removed. A hole was drilled on each side just lateral to the opening with a No. $1 / 2$ dental burr and small screws run into the guide holes. The screws used were the smallest available from the accumulated assortment of a local watchmaker.

The fish was placed in the head holder, and stereotaxic placement of the cannula was accomplished under a dissecting microscope using a modification of the procedures described by Macey et al. (1974). The outer tip of the cannula was inserted about $1 \mathrm{~mm}$ into a $2-\mathrm{cm}$ length of No. $20 \mathrm{PE}$ tubing that was held in an alligator clip carrier of the stereotaxic instrument. The cannula was placed in the third ventrical at the anterior-posterior plane of the nucleus preopticus, using the following coordinates: $+.7 \mathrm{~mm}$ anterior-posterior, midline, and $-1.4 \mathrm{~mm}$ dorsal-ventral (Peter, Macey, \& Gill, 1975). With the cannula held in place, the vacant cranial space was filled with physiological saline (Burnstock, 1958) and a large scale was cut so as to fit around the cannula and cover the skull opening. Dental acrylic (Lang Dental Mfg. Co., Chicago) was mixed with a micro-spatula and filled around the cannula and the anchoring screw heads. A colored bead was embedded in the acrylic for identification purposes. The cannula was then detached from the stereotaxic carrier, and after the acrylic began to harden, a removable cap, made of No. $20 \mathrm{PE}$ tubing closed at the top with the head from a No. 00 insect pin and a drop of Duradix glue, was put on the end of the cannula.

The fish was placed in a 1-gal glass jar under aeration for recovery and was returned to the home tank the next morning or on a later date depending on when it began to eat.

\section{Intracranial Injection Procedure}

A short length of No. 20 PE plastic tubing was attached to the needle of a $5 \mu \mathrm{l}$ Hamilton syringe containing distilled water, and a small volume was ejected into the proximal end of the tubing. The injection solution was then drawn into the dry end of the tube, leaving a short air gap between the solution and the water. The unanesthetized fish was firmly held, wrapped in wet filter floss in a grooved board, the cap was removed from the brain cannula, and a wire of correct length was inserted to clear the lumen of possible obstruction, but not extending beyond the tip of the cannula. While one operator slowly pressed the plunger of the syringe to inject the required $.3 \mu \mathrm{l}$, the other watched to observe that the meniscus moved along the plastic tube, that there was no rebound resulting from compression of the air gap, and that no fluid escaped at the junction with the brain cannula. These precautions ensured, to the best of our belief, that the required volume entered the brain and that there was no spillage. The injection tube was then removed and the cap replaced.

\section{Hormones}

Concentrated stock solutions of $\alpha$ - and $\beta$-MSH, prepared in $.6 \% \mathrm{NaCl}$ containing $.05 \%$ acetic acid, were kept under refrigeration and diluted as required with $.6 \% \mathrm{NaCl}$. In preparing the stock solutions, approximately $1-\mathrm{mg}$ samples were accurately weighed on an Ainsworth microbalance and diluted with the appropriate volume delivered from a Hamilton microsyringe; for stirring we employed a magnetic "flea." Final dilutions for intracranial injection were usually such that $1 \mu \mathrm{g}$ was contained in $.3 \mu \mathrm{l}$, the required volume that was known to contribute $.1 \mu \mathrm{g}$ for the dead space in the cannula and $.2 \mu \mathrm{l}$ to enter the brain ventricle. With accurate delivery, each fish received $.67 \mu \mathrm{g}$. The same dose, contained in $100 \mu \mathrm{l}$, was used for intraperitoneal injections. Preliminary unpublished investigations had shown that as little as $.02 \mu \mathrm{g} / \mathrm{fish}$ of $\beta$-MSH, injected into the body cavity, elicited darkening of the caudal band, but, to ensure decisive results, the higher dose was selected as standard. However, in some tests, as indicated in Table 1, a greater dilution was employed. 


\section{RESULTS}

Inspection of the brain sections showed that 10 of the 16 operated fish were correctly cannulated, without brain injury, and that India ink was present in the third ventricle. Three fish were rejected because of brain injury with widespread seepage of India ink, and one was rejected because the cannula was probably occluded as no India ink was detected either in the ventricle or outside the brain. Two other rejects showed abnormal placement of the cannula, which penetrated the floor of the brain case. The average weight of the 10 correctly cannulated fish was $10.1 \pm .7$ (SEM) $\mathrm{g}$.

No abnormal behavior, such as that described in mammals (Ferrari, 1958; Kastin et al., 1975), was observed after either intraperitoneal or intracranial injections. In fact, the only observable response was the darkening of the faded caudal band. This darkening invariably occurred after intraperitoneal injection (Table 1); the latency before the first detected change averaged $10.7 \pm .9$ (SEM) min, and only in one instance (Fish 4 in one of three tests) was a latency as high as $20 \mathrm{~min}$ recorded. At the lower dose $(.14 \mu \mathrm{g} /$ fish), two recipients gave a minimal response (rating of 1) to intraperitoneal injection, but at the standard dose $(.67 \mu \mathrm{g} /$ fish) all fish responded with a rating of 2 or 3 .

The situation was strikingly different when the injection was given into the third ventricle: 7 fish were totally unresponsive, and in 3 others (Fish 4 , 8, and 9) a minimal darkening was detected after a long latency. Escape of some of the hormone into the blood stream is possible but unlikely, since, although sections indicated an open channel from the tip of the cannula perforating the ventral surface of the brain, there was no apparent vascular injury. Even including these fish, statistical tests show the differences to be highly significant. None of the 10 fish had a shorter mean latency score, regardless of dosage, with the intracranial injections than with the intraperitoneal injections. The mean rating of extent of darkening was greater for intraperitoneal than for intracranial injections in all 10 cases. Application of the sign test yielded a $\mathrm{p}=.002$ (Siegel, 1956). In this connection, the rejected fish that showed brain damage and widespread escape of India ink are of interest: all 3 responded promptly and vigorously to intracranial injection, implicating an escape of hormone into the peripheral circulation.

\section{DISCUSSION}

The results of the present investigation indicate that the melanophore dispersing hormones, $\alpha$ - and $\beta$-MSH, injected into the third cerebral ventricle of
Table 1

Darkening of Faded Denervated Caudal Bands in Killifish After Intraperitoneal or Intracranial Injections of $\alpha$ - or $\beta$-MSH

\begin{tabular}{|c|c|c|c|c|c|c|c|}
\hline \multirow[b]{2}{*}{ Fish } & \multirow[b]{2}{*}{ Peptide } & \multirow{2}{*}{$\begin{array}{r}\text { Dose } \\
\mu \mathrm{g} / \text { Fish }\end{array}$} & \multirow[b]{2}{*}{ Day } & \multicolumn{2}{|c|}{$\begin{array}{c}\text { Intra- } \\
\text { peritoneal }\end{array}$} & \multicolumn{2}{|c|}{$\begin{array}{l}\text { Intra- } \\
\text { cranial }\end{array}$} \\
\hline & & & & $\mathrm{L}^{*}$ & $\mathrm{D}^{* *}$ & $\mathbf{L}$ & D \\
\hline 1 & $\beta-\mathrm{MSH}$ & $\begin{array}{l}.14 \\
.67 \\
.67 \\
.67\end{array}$ & $\begin{array}{l}1 \\
5 \\
7 \\
9\end{array}$ & $\begin{array}{r}10 \\
8\end{array}$ & $\begin{array}{l}2 \\
3\end{array}$ & $\begin{array}{l}>60 \\
>60\end{array}$ & $\begin{array}{l}0 \\
0\end{array}$ \\
\hline 2 & $\beta$-MSH & $\begin{array}{l}.14 \\
.67 \\
.67\end{array}$ & $\begin{array}{l}1 \\
5 \\
7\end{array}$ & 11 & 3 & $\begin{array}{l}>60 \\
>60\end{array}$ & $\begin{array}{l}0 \\
0\end{array}$ \\
\hline 3 & $\beta$-MSH & $\begin{array}{l}.14 \\
.67 \\
.67 \\
.67\end{array}$ & $\begin{array}{l}1 \\
5 \\
7 \\
9\end{array}$ & $\begin{array}{r}12 \\
14 \\
8\end{array}$ & $\begin{array}{l}1 \\
2 \\
3\end{array}$ & $>60$ & 0 \\
\hline 4 & $\beta-\mathrm{MSH}$ & $\begin{array}{l}.14 \\
.67 \\
.67 \\
.67\end{array}$ & $\begin{array}{l}1 \\
5 \\
7 \\
9\end{array}$ & $\begin{array}{r}15 \\
7 \\
20\end{array}$ & $\begin{array}{l}2 \\
2 \\
2\end{array}$ & 20 & 1 \\
\hline 5 & $\beta$-MSH & $\begin{array}{l}.14 \\
.67 \\
.67 \\
.67\end{array}$ & $\begin{array}{l}1 \\
5 \\
7 \\
9\end{array}$ & 14 & 3 & $\begin{array}{l}>60 \\
>60 \\
>60\end{array}$ & $\begin{array}{l}0 \\
0 \\
0\end{array}$ \\
\hline 6 & $\beta$-MSH & $\begin{array}{l}.14 \\
.67 \\
.67 \\
.67\end{array}$ & $\begin{array}{l}1 \\
5 \\
7 \\
9\end{array}$ & $\begin{array}{l}5 \\
9\end{array}$ & $\begin{array}{l}2 \\
3\end{array}$ & $\begin{array}{l}>60 \\
>60\end{array}$ & $\begin{array}{l}0 \\
0\end{array}$ \\
\hline 7 & $\alpha-\mathrm{MSH}$ & $\begin{array}{l}.67 \\
.34 \\
.67\end{array}$ & $\begin{array}{l}1 \\
3 \\
5\end{array}$ & 12 & 2 & $\begin{array}{l}>60 \\
>60\end{array}$ & $\begin{array}{l}0 \\
0\end{array}$ \\
\hline 8 & $\alpha-\mathrm{MSH}$ & $\begin{array}{l}.67 \dagger \\
.34 \\
.67\end{array}$ & $\begin{array}{l}1 \\
3 \\
5\end{array}$ & $\begin{array}{r}12 \\
9\end{array}$ & $\begin{array}{l}1 \\
2\end{array}$ & 38 & 1 \\
\hline 9 & $\alpha-\mathbf{M S H}$ & $\begin{array}{l}.67 \\
.34 \\
.67\end{array}$ & $\begin{array}{l}1 \\
3 \\
5\end{array}$ & $\begin{array}{r}8 \\
12\end{array}$ & $\begin{array}{l}3 \\
3\end{array}$ & 45 & 1 \\
\hline 10 & $\alpha$-MSH & $\begin{array}{l}.67 \\
.34 \\
.67\end{array}$ & $\begin{array}{l}1 \\
3 \\
5\end{array}$ & 7 & 3 & $\begin{array}{l}>60 \\
>60\end{array}$ & $\begin{array}{l}0 \\
0\end{array}$ \\
\hline
\end{tabular}

*Latency in minutes to first detectable darkening.

**Maximum darkening during 60 min: $0=$ no change, $1=$ minimal detectable darkening, 2 = definite darkening, $3=$ intense darkening.

$\dagger$ Dose possibility greater since there was an initial external leakage and an additional $.2 \mu l$ was given.

the killifish, can enter the peripheral circulation with difficulty, if at all. In a preliminary investigation (unpublished), we found that a dose as low as .02 $\mu \mathrm{g}$ / fish could elicit darkening of the faded caudal band when administered by intraperitoneal injection. Thus, at least $3 \%$ of the dose $(.67 \mu \mathrm{g})$ injected into the third ventricle may have passed the CSF-blood barrier of the three fish that gave a minimal response provided, as we believe, that there was no injury to adjacent blood vessels. In the remaining seven unresponsive fish any hormonal escape must have been of lesser magnitude. 
Recent studies of laboratory rodents have employed the brain uptake index (BUI) of Oldendorf (1971), in which the uptake of a labeled test substance is compared with that of a simultaneously administered tracer, such as tritiated $\mathrm{H}_{2} \mathrm{O}$, which freely passes the blood-brain barrier. In the case of $\alpha-\mathrm{MSH}$, this factor is $9.6 \%$ relative to water (Greenberg et al., 1976). This implies a low, but physiologically significant, level of penetration that probably takes place through the area postrema (Lichtensteiger \& Lienhart, 1977). In the case of mammals, interest has centered on the well-documented behavioral effects resulting from injections of melanophore hormones into the cerebral ventricle (Ferrari, 1958) or into the peripheral circulation (Kastin et al., 1975; van Wimersma Greidanus, Lowry, Scott, Rees, \& De Wied, 1975). No recognizable behavioral effects have been observed in the killifish after either intraperitoneal or intracranial injections, although the primary objective in initiating this research was to ascertain a possible role of the melanophore hormones in the spawning reflex response. This communication is therefore restricted to the melanophore dispersing activity of hormones reaching the pigment cells by way of the general circulation.

The melanophore hormone is normally released from MSH-secreting cells in the pars intermedia of the pituitary, which is outside the blood-brain barrier, and thus enters the capillaries for peripheral distribution. However, reverse transport into the cerebrospinal fluid is possible, since this is thought to occur in the case of the hypothalamic releasing peptides, TSH-RF and LH-RF (Kastin, Nissen, Nikolics, Medzihradszky, Coy, Teplan, \& Schally, 1976) that are discharged into the mammalian median eminence (Knigge, Morris, Scott, Joseph, Notter, Schock, \& Krobisch-Dudley, 1975). Recent articles relating to this problem in teleostean fishes may be cited (Demski \& Evan, 1975; Jansen, de Weger, Woutersen, van Loveren, \& van de Kamer, 1976; ObermüllerWilén, 1973; Polenov, Belenky, Garlov, \& Konstantinova, 1976; Vigh-Teichmann, Vigh, \& Aros, 1975). A block to the entry of MSH into the blood stream most probably resides in a lack of permeability of the capillary network of the brain. In respect to the all-too-sparse literature on teleostean fishes, intraperitoneal injections of trypan blue, or related dyes, fail to enter the substance of the brain, although the choroid plexus may be colored (Bernstein \& Streicher, 1965; Lundquist, 1942). Intraventricular injections of peroxidase or lanthanum, although taken up by the endothelial cells of the choroid plexus of the 3rd and 4th ventricle, fail to enter the adjacent capillary vessels of the roach (Obermüller-Wilén, 1972). In contrast to these nonpenetrating substances, Rahmann (1970) states that there is no blood-brain barrier to the incorporation of palmitic acid into the teleostean nervous system. These findings suggest that the blood-brain barrier of the teleostean brain is functionally similar to that of higher vertebrates.

Other aspects of the problem have not been studied in bony fishes: enzymatic degradation of the melanophore hormones, recently investigated in mammals (Marks, Stern, \& Kastin, 1976), undoubtedly occurs, but the mean latency of the response, observed in the present investigation, suggests that the degradation process may be slow in poikilotherms. Another interesting line of investigation would be the opening of the blood-brain barrier, as by intra-arterial injection of urea, which has proved to be a profitable area of research in mammals (Pickard, Durity, Welsh, Langfitt, Harper, \& Mackenzie, 1977).

\section{REFERENCES}

Aronson, L. R. An analysis of reproductive behavior in the mouthbreeding cichlid fish, Tilapia macrocephala (Bleeker). Zoologica, Scientific Contributions of the New York Zoological Society, 1949, 34, 133-158.

Bernstein, J. J., \& Streicher, E. The blood-brain barrier of fish. Experimental Neurology, 1965, 11, 464-473.

Burnstock, G. Saline for freshwater fish. Journal of Physiology, 1958, 141, 35-45.

Cserr, H. F., Fenstermacher, J. D., \& Rall, D. P. Brainbarrier systems in sharks. Comparative Biochemistry and Physiology, 1972, 42A, 73-78.

Demski, L. S., \& Evan, A. P. Golgi studies on CSF contacting cells on the third ventricle in teleosts. Anatomical Record, 1975, 181, 343. (Abstract)

Fenstermacher, J. D., \& Patlack, C. S. CNS, CSF, and extradural fluid uptake of various hydrophilic materials in the dogfish. American Journal of Physiology, 1977, 232, R45-R53.

Fenstermacher, J. D., Patlack, C. S., \& Blasberg, R. G. Transport of material between brain extracellular fluid, brain cells and blood. Federation Proceedings, 1974, 33, 2070-2074.

FERRARI, W. Behavioural changes in animals after intracisternal injection with adrenocorticotropic hormone and melanocyte stimulating hormone. Nature, 1958, 181, 925-926.

Greenberg, R., Whalley, C. E., Jourdikian, F., Mendelson, I. S., Walter, R., Nikolics, K., Coy, D. H., Schally, A. V., \& Kastin, A. J. Peptides readily penetrate the blood-brain barrier: Uptake by synaptosomes is passive. Pharmacology, Biochernistry and Behavior, 1976, 5 (Supplement 1), 151-158.

JANSEN, W. R., De Weger, R. A., Woustersen, R. A., VAN Loveren, H., \& van De Kamer, J. C. The saccus dorsalis of the rainbow trout, Salmo gairdneri Richardson. Histological, cytochemical, electron microscopical and autoradiographical observations. Cell and Tissue Research, 1976, 167, 467-491.

Kastin, A. J., Nissen, C., Nikolics, K., Medzihradszky, K., Coy, D. H., Teplan, I., \& Schally, A. V. Distribution of H-a-MSH in rat brain. Brain Research Bulletin, 1976, 1, 19-26.

Kastin, A. J., Sandman, C. A., Stratton, L. D., Schally, A. V., \& Miller, L. H. Behavioral and electrographic changes in rat and man after MSH. Progress in Brain Research, $1975,42,143-150$.

Knigge, K. M., Morris, M., Scott, D. R., Joseph, S. A., Notter, M., Schock, D., \& KRobisch-Dudley, D. Distribution of hormones by cerebrospinal fluid. In H. F. Cserr, 
J. D. Fenstermacher, \& V. Fencl (Eds.), Fluid environment of the brain. New York: Academic Press, 1975.

LICHTENSTEIGER, W., \& LIENHART, R. Response of mesencephalic and hypothalamic dopamine neurons to a-MSH: Medicated by area postrema? Nature, 1977, 266, 635-637.

LiNDQUIST. F. The blood-brain barrier in some freshwater teleosts. Acta Physiologica Scandinavica, 1942, 4, 201-206.

Macey, M. J.. Pickford, G. E., \& Peter, R. E. Forebrain localization of the spawning reflex response to exogenous neurohypophysial hormones in the killifish, Fundulus heteroclitus. Journal of Experimental Zoology, 1974, 190, 269-280.

Marks, N., Stern, F., \& Kastin, A. J. Biodegration of a-MSH and derived peptides by rat brain extracts, and by rat and human serum. Brain Research Bulletin, 1976, 1 , 591.593

Murray. M. Brain barrier systems in cyclostomes. In H. F. Cserr, J. D. Fenstermacher. \& V. Fencl (Eds.), Fluid environment of the brain. New York: Academic Press, 1975. (Fluid environment of the Brain Proceedings Symposium, 1974.)

Murray, M., Jones, H., Cserr, H. S., \& Rall, D. P. Bloodbrain barrier and ventricular system of Myxine glutinosa. Brain Research, 1975, 99. 17-33.

OBERMÜLLER-WILÉN. H. Uptake of peroxidase and lanthanum by the teleost choroid plexus. Acta Zoologica, 1972, 53, 219-228.

OBERMüller-Wilén. H. Fine structure and histochemistry of the choroid plexus of the teleost, Leuciscus rutilus. Acta Zoologica, 1973, 54, 1-8.

OldendORF. W. H. Brain uptake of radiolabeled amino acids, amines and hexoses after arterial injection. American Journal of Physiology'. 1971, 221. 1629-1639.

PARKer, G. H. Animal colour changes and their neurohumours. Cambridge: Academic Press, 1948.

Peter. R. E.. \& Billard, R. Effects of third ventricle injection of prostaglandins on gonadotropin secretion in goldfish, Curassius auratus. General and Comparative Endocrinology, 1476. 30, 451-456.
Peter, R. E., Macey, M. J.. \& Gill, V. E. A stereotaxic atlas and technique for forebrain nuclei of the killifish, Fundulus heteroclitus. Joumal of Comparative Neurology. 1975, 159. 103-128.

Pickard. J. D.. Durity, F., Welsh, F. A., Langfitt, T. W., Harper, A. M., \& MacKenzie, E. T. Osmotic opening of the blood-brain barrier: Value in pharmacological studies on the cerebral circulation. Brain Research, 1977, 122, 170-176.

Pickford, G. E. A study of the hypophysectomized male killifish, Fundulus heteroclitus (Linn.). Bulletin of the Bingham Oceanographic Collection, 1953, 14(2), 5-41.

Polenov, A. L., Belenky, M. A., Garlov, P. E., \& Konstantinova, M. S. The hypothalamo-hypophysial system in Acipenseridae. VI. The proximal neurosecretory contact region. Cell and Tissue Research. 1976, 170, 129-144.

RahmanN, H. Transport von $3 \mathrm{H}$-Palmitensäure im ZNS von Teleosteern. Zeitschrift für Zellforschung und mikroskipische Anatomie, 1970, 110, 444-456.

SIEGEL. S. Nonparametric statistics for the behavioral sciences. New York: McGraw-Hill, 1956.

van Wimersma Greidanus, T. B., Lowry, P. J., Scott, A. P., ReEs, L. H., \& DE WIED, D. The effects of dogfish MSH's and of corticotrophin-like intermediate lobe peptides (CLIP's) on avoidance behaviour in rats. Hormones and Behaviour. 1975. 6. 319-327.

Vigh-Teichmann, I., Vigh, B., \& Aros, B. Cerebrospinal fluid-contacting neurons, ciliated perikarya and "peptidergic" synapses in the magnocellular preoptic nucleus of teleostean fishes. Cell and Tissue Research. 1975, 165, 397-413.

WARING, H. Color change mechanisms of cold-blooded vertebrates. New York: Academic Press, 1963.

(Received for publication June 6, 1977; revision accepted October $26,1977$. 